\title{
GENDER QUOTA IN THE BOARDROOM: THE DUTCH APPROACH
}

\author{
MIJNTJE LÜCKERATH-ROVERS*
}

\begin{abstract}
Since 2013 the Dutch Civil Code has required a minimum of 30 per cent women (and men) on both the executive and the supervisory boards of companies. The law is based on the comply or explain principle: companies that have not reached the 30 per cent target on one or other of these Boards should explain in their annual report why the seats are not evenly distributed, how the company has tried to achieve a balanced distribution of the seats and how the company intends in future to realise a balanced distribution of the seats. Research among the 87 listed companies in the Netherlands shows that the average percentage of women on supervisory boards increased to 25 per cent in 2014, but that the percentage on executive boards increased only to 6 per cent. While the 30 per cent target should have been reached by January 2016, it seems only a matter of time before a quota with sanctions will be introduced in the Netherlands.
\end{abstract}

\section{INTRODUCTION}

After almost two decades of sometimes heated debate, the Management and Supervision Act (the 'Act'), including gender targets for Dutch boards, became effective on 1 January 2013. This Act introduced provisions aiming to ensure a balanced distribution of seats between men and women on both the executive and supervisory boards of large Dutch corporations (public limited companies (NVs) and private limited companies (BVs)). In the Netherlands, the two-tier board structure consisting of an executive board and a supervisory board is predominantly used. This means that the executive board and the supervisory board are two separate boards. In order to facilitate international comparison, this article will use international terminology: the executive board members will be referred to as the executive directors, whereas the supervisory board members will be called the non-executive directors.

\footnotetext{
* Prof dr Mijntje Lückerath-Rovers is Professor of Corporate Governance at Tilburg University/ TIAS School for Business and Society, the Netherlands. E-mail: m.luckerath@tias.edu.
} 
According to the Act a balanced distribution means that at least 30 per cent of the board seats are occupied by men and at least 30 per cent are occupied by women. Companies subject to the scheme, but which have not reached the desired targets, must explain in the annual report ('comply or explain') why the seats are not evenly distributed, how the company has tried to balance the distribution of seats, and how the company seeks to achieve the balance of seats in the future. No further sanctions are included. The duration of the statutory provision is limited. The legislative items, in force since January 2013, will automatically be repealed from 1 January 2016.

This article proceeds as follows. Part II describes the history of the target law and shows that it took almost two decades for it to be incorporated into Dutch Civil Law. The issue of gender targets for board composition began being addressed in 1996, with the debate becoming more heated thereafter. Initiatives based on company self-regulation did not have the desired impact, and legislation was proposed in 2008. It took another five years before this was actually included in the Dutch Civil Law. The debate has intensified since September 2014, when it became clear that the legislated targets would not be reached by 1 January 2016. Part III describes the relevant aspect of the target law. Part IV describes the development of the actual percentages for both the executive board and the supervisory board of Dutch listed companies over the period 2005-2014. Part V concludes with some remarks regarding future developments and outlook.

\section{The history OF Dutch Gender TARget LaW}

\section{A 1996-2006: Addressing the Issue}

Since 1996 there have been many initiatives, all with the same goal: increasing the number of women in top positions. In 1996 a governmental grant was awarded to a foundation that advocated that diversity is of strategic importance, and that a balanced business team will perform better than an unbalanced one. Furthermore, in 2000 the Ministries of Social Affairs and Employment and Economic Affairs took the initiative to set up an 'Ambassadors' Network'. This Ambassadors' Network was an annually changing group of influential and well known business leaders. Group members committed themselves for one year in order to promote the appointment of women to senior and top positions. 


\section{B 2006-2008: Initiatives in Self-Regulation}

It took almost a decade for the Dutch government to take further action. This it did by means of a policy entitled: 'Emancipation: It's obvious but it doesn't happen by itself!' ('the Emancipation policy'). ${ }^{1}$ In this policy the Dutch government set six objectives to support emancipation in a broader societal context. $^{2}$ The policy presented these objectives as being beneficial for women themselves, for society as a whole, and for the future. Included amongst the objectives were: that more women should be employed, that women should work more hours, and that their talents and skills should be better utilised. The fifth objective was 'to achieve a proportionate representation of women in decision-making positions'. ${ }^{3}$ More specifically, the policy proposed that the proportion of women in top jobs in the corporate world should increase to 20 per cent by 2010.

This in turn led to the development during 2007 of the Charter 'Talent to the Top', an initiative of the government, together with the employers' union VNONCW, the Social-Economic Council (SER) and the labour union FNV. This initiative strives to force government, business and women themselves to promote female talent to the top through structural change. The Charter, which was presented in May 2008, was initially signed by 47 companies and government agencies. Although none of the emancipation goals described above have yet been met, it appeared at that stage that the 'sense of urgency' had finally reached the top management of organisations. However, regrettably, the previously described Ambassadors' Network ceased to exist due to the foundation of this 'Talent to the Top' initiative, which resulted in no visible business leaders addressing the issue on a regular basis. Signing the Charter 'Talent to the Top' is voluntary; companies commit themselves to their own targets, and annually report on their progress towards these targets.

However, the voluntary Charter was not sufficiently progressive for the Dutch Labour Party. The Labour party filed a motion instructing the Minister of Finance to request the Corporate Governance Code Committee responsible for changing the Corporate Governance Code to include targets for women on

\footnotetext{
1 'Meerjarenbeleidsplan Emancipatie 2006-2010 Emancipatie: Vanzelfsprekend, Maar Het Gaat Niet Vanzelf! (29 December 2005) Overheid.nl!' <https://zoek.officiele bekendmakingen.nl/kst-30420-2.html>.

2 The Netherlands, Parliamentary Speech, Tweede Kamer [House of Representatives], 19 December 2005, 30 420, nr 2 [author's translation].

${ }^{3}$ Emancipatie: Vanzelfsprekend, Maar Het Gaat Niet Vanzelf!, above n 1, 11, Main objective 5.
} 
boards of directors and supervisory boards. ${ }^{4}$ The motion requested a target percentage of between 25 and 30 per cent by 2015 .

A majority of the Dutch Parliament voted in favour of this motion (in April 2008), and the motion was therefore adopted. However, the Minister of Finance ignored the motion and argued that any pressure on the Committee would affect and harm the self-regulatory character of the Corporate Governance Code. The Minister therefore suggested that the members of parliament should decide on legislation if they believed that self-regulation was not having the desired effect. In a reaction to the Minister the Labour Party stated ${ }^{5}$ that it would indeed file for legislation to impose a statutory obligation if the targets were not included the Corporate Governance Code.

Nevertheless, the Committee did experience political, social and media pressure to include a specific target (a percentage) for women on executive and supervisory boards in the revised Corporate Governance Code. During 2008 the Committee acknowledged the need for increased attention to women in top positions, and also highlighted the importance of diversity (including diversity on the basis of gender, age, experience and social background) in the section that addressed the performance of the supervisory board. The Committee also stated that companies gain direct benefit from promoting women to top positions since a key success factor for companies is attracting and retaining talent. ${ }^{6}$

However, at the end of 2008, when the revised Corporate Governance Code ${ }^{7}$ was presented, the Committee did not include any specific diversity target. The principle addressing diversity (Principle III.3 on 'Expertise and Composition') includes an encouragement to companies to pursue a mixed board composition, referring specially to gender and age. The Code requires that supervisory boards should also include in their reports their specific goals with respect to diversity. If the intended goal has not been reached, the supervisory board should explain how and within what period it expects to achieve the goal. According to the Code, the pursuit of a mixed composition should be reflected in the profile of

${ }^{4}$ Second Chamber of the States General, Parliamentary Paper 31083-17 (8 May 2008) $<$ https://zoek.officielebekendmakingen.nl/kst-31083-17.html>.

5 Second Chamber of the States General, Parliamentary Paper 31083-21 (6 June 2008) $<$ https://zoek.officielebekendmakingen.nl/dossier/31083/kst-31083-21?resultIndex=66\& sorttype $=1 \&$ sortorder $=4>$.

${ }^{6}$ Monitoring Commission Corporate Governance Code, Rapport evaluatie en actualisering Nederlandse corporate governance code (2008) <http://commissiecorporate governance.nl/evaluatierapport-juni-2008>.

${ }^{7}$ Monitoring Commission Corporate Governance Code, De Nederlandse Corporate Governance Code (2009) <http://commissiecorporategovernance.nl/corporate-governance-code> . 
the supervisory board. However, no such recommendation was made regarding the composition of the executive board. Furthermore, the Committee argued that a company itself can best assess how these goals can be given effect to, and this is the company's responsibility.

\section{2008: First Steps to Legislation}

As mentioned, the Labour Party took the initiative to file for a Bill to introduce targets into the Civil Code for the participation of women on both the executive and the supervisory boards of 'large' Dutch companies - public listed companies and limited liability companies. It should be noted that the Corporate Governance Code applies only to listed companies, which numbered around 120 companies at that time, whereas the definition of 'large' companies would have included over 4000 companies. The proposal required a 'balanced' distribution of board seats, indicating that the term 'balanced' means that at least 30 per cent of the seats on both the executive and supervisory boards must be occupied by each gender.

It should be noted that this proposal was part of a larger package of several proposals, all combined in one Act - the Management and Supervision Act. The initial Bill, before the other proposals were added, was filed to legislate a right for Dutch public companies to structure themselves on a one-tier board model. This would make it easier for Dutch companies to operate in an international context. This original Bill was not at all controversial and the desirability of a legal right to choose the one-tier board model was widely acknowledged. However additional proposals were added to this Bill, including a highly controversial proposal by the Socialist Party to limit the number of supervisory board positions to a maximum of five per individual person. The Socialist Party's intention was to break the 'old-boys network', by virtue of which, they argued, most board positions are shared by the same group of people. The gender target proposal of the Labour Party was also attached to this Bill but, presumably because no sanctions were included, did not receive as much attention as the maximum board positions proposal.

\section{2008-2013: Five Years before the Law Became Effective}

It took almost five years before the Act came into effect on 1 January 2013. The Dutch Senate can only vote on a Bill in its entirety. It cannot pick and choose selectively the proposals which it votes for, or against. For this reason, it took some time before the Bill passed the Senate. In particular, certain critical aspects of the proposal of a maximum number of supervisory board positions 
had to be resolved first. ${ }^{8}$ Therefore, although the majority of the Second Chamber voted for this Act in November 2009, ${ }^{9}$ the Senate did not decide positively to pass the legislation until almost two years later (May 2011). The Act was published in the Dutch Bulletin of Acts and Decrees on 6 June 2011. However, at that time the date at which the Act would come into effect was not yet agreed upon, whereas the termination date of the articles of the gender target was already set at 1 January 2016, regardless of the date the Act came into effect. Termination would not occur for another two years, and so, on 1 January 2013, the full Act became effective.

\section{ARgUMENTS FOR MORE DIVERSITY}

Unfortunately, in the Netherlands the debate around the paucity of women in top management teams is still overwhelmingly discussed in normative terms, focusing on what is 'right' and 'wrong'. Yes-no questions are asked: 'Are there, or are there not, enough women to fill the places?'; 'Is it, or is it not, a form of discrimination?'; 'May, or may not, women be entitled to a place at the top?'; 'Is there, or is there not, a glass ceiling, an old-boys network, adequate childcare, and so on?' In the debate about 'women to the top', moral and economic arguments for more women at the top are used interchangeably. However, it would be desirable to make a clearer distinction between these arguments; this may hopefully result in the discussion becoming slightly more nuanced. Brammer, Millington and Pavelin ${ }^{10}$, for example, divided the arguments for more women on the board into i) arguments from a business perspective and ii) arguments from a moral (ethical) perspective. Furthermore, the authors divide both the business and the moral arguments into arguments for equal opportunities and arguments for equal representation. Table 1 summarises the four perspectives in the debate about women on boards.

\footnotetext{
${ }^{8}$ There was criticism of the uncertainty of the validity of the decision-making process if a director, who holds more than the permitted positions, participated in the decision making process. The Minister of Justice therefore proposed an amendment under which such participation in decision-making will not affect the legal validity of the decision taken <https://www.eerstekamer.nl/behandeling/20111209/nota_van_wijziging_3/document3/f=/viv 8wgyi1syc.pdf $>$.

9 Parliamentary Paper I 2009/10. 31763 nr A <https://zoek.officielebekendmakingen.nl/ dossier/31763/kst-20092010-31763-A?resultIndex=23\&sorttype=1\&sortorder=4>.

${ }^{10}$ Stephen Brammer, Andrew Millington and Stephen Pavelin, 'Gender and Ethnic Diversity among UK Corporate Boards’ (2007) 15(2) Corporate Governance: An International Review 393, 394.
} 
Table 1. Business and moral arguments in the debate about the absence of women on the board (Arguments derived from Brammer et al)

\begin{tabular}{|c|c|c|}
\hline & Economic arguments & Moral (ethical) arguments \\
\hline $\begin{array}{c}\text { Equal } \\
\text { opportunities }\end{array}$ & $\begin{array}{l}\text { The economic case for equal } \\
\text { opportunities for women } \\
\text { focuses on the fact that the } \\
\text { absence of women is } \\
\text { suboptimal for the company. } \\
\text { Failure to choose the most } \\
\text { suitable candidate affects the } \\
\text { financial performance of the } \\
\text { company. If certain valuable } \\
\text { qualities are not evenly } \\
\text { distributed among } \\
\text { demographic groups, the } \\
\text { company is structurally } \\
\text { denying these qualities by } \\
\text { excluding women from } \\
\text { decision-making positions. }\end{array}$ & $\begin{array}{l}\text { Moral arguments for equal } \\
\text { opportunities are based on the } \\
\text { idea that it is wrong to keep } \\
\text { individuals from the board } \\
\text { simply because of gender or } \\
\text { race, regardless of ability. This } \\
\text { is a form of discrimination. }\end{array}$ \\
\hline $\begin{array}{c}\text { Equal } \\
\text { representation }\end{array}$ & $\begin{array}{l}\text { Economic arguments for equal } \\
\text { representation refer to the } \\
\text { direct and indirect interest the } \\
\text { board has in reflecting the } \\
\text { (demographic characteristics } \\
\text { of) stakeholders of the } \\
\text { company, such as consumers, } \\
\text { employees and investors. }\end{array}$ & $\begin{array}{l}\text { The under-representation of } \\
\text { women and other groups on the } \\
\text { board excludes these groups } \\
\text { from economic power, and } \\
\text { should be ended. This argument } \\
\text { is somewhat similar to } \\
\text { arguments for voting rights for } \\
\text { all. The presence of more } \\
\text { women on the board would be a } \\
\text { more just and equitable } \\
\text { outcome for society. }\end{array}$ \\
\hline
\end{tabular}

\section{A Economic Arguments}

\section{Equal Opportunities}

The economic case for equal opportunities for women focuses on the fact that the absence of women is suboptimal for the company. Failure to choose the most suitable candidate affects the company performance. Analogous to this argument is that an absence of women at the top signals that a company is operating less than optimally. If certain valuable qualities are not evenly 
distributed among demographic groups, the company is structurally denying these qualities by excluding women from decision-making positions. ${ }^{11}$ Companies with a higher degree of diversity on the board send an important positive signal to (potential) employees of that company; the competitive situation within (between employees) and outside the company (between potential employees) is strengthened, ${ }^{12}$ and performance will improve. ${ }^{13}$ Wellqualified (external) candidates for directorships see that they may be eligible for a vacant position, even if they are outside the circle from which board members are normally recruited. In addition, diversity fuels internal competition among employees (and improves their performance) because of the positive signal to 'minorities' that everyone can achieve a directorship, regardless of their demographic characteristics.

\section{Equal Representation}

Economic arguments for equal representation refer to the direct and indirect interest of the board in reflecting the (demographic characteristics of) stakeholders of the company, such as consumers, employees and investors. A more diverse board provides a better understanding of the markets and customers of the company. Society also regards a higher degree of diversity as positive, and the reputation of the company improves. When the diversity within the company and its management reflects the diversity within the relevant market, a company is better able to serve and retain that market. ${ }^{14}$

\section{B Moral Arguments}

\section{Equal Opportunities}

The moral arguments for equal opportunities are based on the idea that it is wrong to deny individuals board membership simply because of gender or race, and regardless of ability. Denying equal opportunity is a form of discrimination.

\footnotetext{
${ }^{11}$ Ibid 395.

${ }^{12}$ Caspar Rose, 'Does Female Board Representation Influence Firm Performance? The Danish Evidence’ (2007) 15(2) Corporate Governance: An International Review 404, 405.

${ }^{13}$ Jeffrey Pfeffer and Gerald R Salanick, The External Control of Organisations: A Resource Dependence Perspective (Harper \& Row, 1978) 106-7.

${ }^{14}$ Ibid.
} 


\section{Equal Representation}

The moral arguments for equal representation focus on the fact that the presence of more women on the board would be a more just and equitable outcome for society as a whole. ${ }^{15}$ The moral arguments are based on the social responsibility of enterprises and their management: being a good corporate citizen, for instance through non-discrimination, compliance with (social) norms and values ${ }^{16}$ On the other hand, according to Rose, ${ }^{17}$ it is not appropriate to impose democratic ideas from the public domain (such as voting rights for all) on companies, because the principles in a company are very different from the principles in society.

Although the moral arguments for increasing board diversity are connected with the economic arguments, for example through the impact of reputation on financial returns, previous research on the relationship between board diversity and company performance mostly relates to the economic arguments.

\section{THE TARget LAW}

\section{A 4500 Companies}

The target provisions apply to larger limited liability companies and publicly listed companies ('PLCs'). These types of company are not subject to the proposed statutory provision if they meet two of the following three requirements: ${ }^{18}$

a) The value of the assets according to its balance sheet does not exceed $€ 17500$ 000;

b) Net sales for the financial year do not exceed $€ 35000$ 000;

c) The average number of employees for the financial year is less than 250.

Companies are exempted from the target law if they meet fewer than two of the criteria. Thus, companies must comply with the target if they do meet two of the criteria. Based on these criteria the number of companies

\footnotetext{
${ }^{15}$ Brammer, Millington and Pavelin, above n 10, 395.

${ }^{16}$ Ibid 396.

${ }^{17}$ Rose, above n 12, 405.

${ }^{18}$ In accordance with the Civil Code art 2:397 para 1.
} 
in the Netherlands that would be subject to this proposal was estimated. In 2012 more than 2.2 million companies were registered with the Dutch Chamber of Commerce, including more than 1 million registered as limited liability companies or PLCs. More than 5000 of these companies have a balance sheet total that exceeds $€ 17.5$ million, and more than 11000 have a turnover in excess of $€ 35$ million. Both criteria combined provided a number of at least 4500 companies that would fall under the quota proposal in 2012. Unfortunately, the number of employees proved to be a poor measurement because many (holding) companies are registered as having only one employee.

\section{B Comply or Explain}

According to article 2:397 of the Dutch Civil Code, a minimum of 30 per cent women (and men) on both the executive and the supervisory board is required. Article 2:397 states that companies must take this target of 30 per cent into account when:

1) nominating and appointing executive directors;

2) preparing a profile of the size and the composition of the supervisory board; and,

3) designating, nominating, recommending and appointing nonexecutive directors, in other words members of the supervisory board.

The requirement is based on the 'comply or explain' principle: companies that have not reached the 30 per cent target on one or other of these Boards should explain in their annual report:

1) why the seats are not evenly distributed;

2) how the company has tried to achieve the balanced distribution of the seats; and

3) how the company intends to realise a balanced distribution of the seats. 


\section{THE EU QuOTA LAW}

In November 2012 the European Commission proposed legislation with the aim of attaining an objective of 40 per cent female ${ }^{19}$ non-executive directors in all publicly listed companies with the exception of small and medium-sized enterprises. ${ }^{20}$ On 20 November 2013 the members of the European Parliament voted this proposal into law with a vote of 459 for, 148 against and 81 abstentions. Now that the proposal has been approved by one of the European Union's two co-legislators, the member States in the Council need to reach agreement among themselves on the draft law and need to elicit the agreement of the European Parliament. ${ }^{21}$

The EU quota law prescribes that companies with fewer than 40 per cent female non-executive directors will be required to make appointments to those positions on the basis of a comparative analysis of the qualifications of each candidate, by applying clear gender-neutral and unambiguous criteria. Given equal qualification, priority shall be given to female directors. ${ }^{22}$

The objective of attaining at least 40 per cent female representation is to be met by 2020 while public undertakings (in which the public authorities have a direct or indirect influence) will have until 2018. ${ }^{23}$ The target does not apply to small or medium-sized enterprises, ${ }^{24}$ or non-listed companies. With respect to executive directors the proposal includes a 'flexi-quota' — an obligation for listed companies to set themselves individual, self-regulatory targets regarding

\footnotetext{
${ }^{19}$ The proposal uses the term 'the under-represented sex'.

${ }^{20}$ European Commission, 'Women on Boards: Commission Proposes 40\% Objective' (Press Release, 14 November 2012) <http://ec.europa.eu/justice/newsroom/gender-equality/news/ 121114_en.htm>.

${ }^{21}$ Ibid.

${ }^{22}$ European Commission, Proposal for a Directive of the European Parliament and of the Council on Improving the Gender Balance among Non-Executive Directors of Companies Listed on Stock Exchanges and Related Measures (14 November 2012) 6 $<$ http://ec.europa.eu/justice/gender-equality/files/womenonboards/directive_quotas_en.pdf>.

${ }^{23}$ In a public undertaking public authorities 'may exercise directly or indirectly a dominant influence by virtue of their ownership of it, their financial participation therein, or the rules which govern it': European Parliament, 'Public Undertakings and Services in the European Union, Economic Series W-21, Part I: The Situation of Public Undertakings in the European Union' (Working Paper, European Parliament) <http://www.europarl.europa.eu/ workingpapers/econ/w21/sum-1_en.htm>.

24 'Companies with less than 250 employees and an annual worldwide turnover not exceeding 50 million EUR': European Commission, above n 20.
} 
the representation of both sexes among executive directors to be met by 2020 . As for the Dutch situation, it would be better to refer to the EU quota law as a 'target law' instead of a 'quota': the target of 40 per cent is not mandatory, and there are no sanctions imposed for non-compliance. However, the EU requires member states to lay down 'appropriate and dissuasive sanctions for companies in breach of the Directive'. ${ }^{25}$ Furthermore, Companies will have to report annually on the progress they have made. Like the Dutch quota law, the Directive is a temporary measure and is set to expire in 2028.

It is uncertain when the EU quota law will become effective, nor when the last steps in the legislation process will be taken.

\section{A $\quad 30$ per cent or $\mathbf{4 0}$ per cent?}

The EU quota requires a minimum of 40 per cent female non-executive directors, which is also the case for Norway. In the Netherlands a minimum of 30 per cent for both non-executive directors and executive directors is required. However, in practice the difference between 30 and 40 per cent is not visible. For example, under the Norwegian quota a minimum of 40 per cent applies strictly to boards with either five or ten directors, leading to the appointment of either two or four female directors. However, under the Norwegian law a scheme is included which requires an actual number of female directors (see Table 2 below) instead of the fixed 40 per cent. Table 1 shows that, for example, according to the scheme, 33 per cent is sufficient when there are three nonexecutive director positions in total. In that case one of them has to be a woman.

Also, in the Netherlands, since it is not possible to appoint 1.3 women, in practice it is only possible to reach the exact number of 30 per cent when the respective Executive and Supervisory Board consist of exactly ten persons. In all other cases, a minimum of 30 per cent means at least 33 per cent and a maximum of 50 per cent (see Table 2 below).

For example a supervisory board with four members should appoint at least two women to reach the minimum requirement of 30 per cent. The female participation on the Supervisory Board then rises to 50 per cent.

25 European Commission, Press release, Women on Boards: Commission proposes $40 \%$ objective (14 November 2012) 3 <http://europa.eu/rapid/press-release_IP-12-1205_en.htm>. 
Table 2. Comparison of a 30 per cent or $\mathbf{4 0}$ per cent quota

\begin{tabular}{|c|c|c|c|c|}
\hline \multirow{2}{*}{$\begin{array}{l}\text { Number of } \\
\text { members in } \\
E B \text { and } S B\end{array}$} & \multicolumn{2}{|c|}{ The Netherlands } & \multicolumn{2}{|c|}{ Norway } \\
\hline & $\begin{array}{c}\text { Minimum } \\
\text { number of } \\
\text { women }\end{array}$ & $\begin{array}{c}\text { Actual } \\
\%\end{array}$ & $\begin{array}{c}\text { Minimum } \\
\text { number of } \\
\text { women }\end{array}$ & $\begin{array}{c}\text { Actual } \\
\%\end{array}$ \\
\hline 2 & 1 & $50 \%$ & 1 & $50 \%$ \\
\hline 3 & 1 & $33 \%$ & 1 & $33 \%$ \\
\hline 4 & 2 & $50 \%$ & 2 & $50 \%$ \\
\hline 5 & 2 & $40 \%$ & 2 & $40 \%$ \\
\hline 6 & 2 & $33 \%$ & 3 & $50 \%$ \\
\hline 7 & 3 & $43 \%$ & 3 & $43 \%$ \\
\hline 8 & 3 & $38 \%$ & 3 & $38 \%$ \\
\hline 9 & 3 & $33 \%$ & 4 & $44 \%$ \\
\hline 10 & 3 & $30 \%$ & 4 & $40 \%$ \\
\hline
\end{tabular}

Table 2 therefore shows that the minimum requirement of 30 or 40 per cent makes a difference for only three board sizes: 1) a board of six directors (two women in the Netherlands is enough, in Norway there have to be three), of nine directors, and of ten directors. On the latter two boards three women are sufficient in the Netherlands, but in Norway there must be four).

\section{The Impact OF These INTENSIFYING PRESSURES}

\section{A The Dutch Female Board Index}

Since 2007, the Dutch Female Board Index has provided an annual overview of the presence of women on the executive and supervisory boards of Dutch listed companies. The Female Board Index follows the example of the Female FTSE Index of Cranfield University in the UK, and ranks listed companies based on the number of female directors on the Board. The last Female Board Index published the numbers as of 31 August 2014.

The Dutch Index covers (all) 87 Dutch listed companies. Because — other than Dutch NVs - companies listed on the stock and derivatives exchange (Euronext Amsterdam) are not included in the Index, the Dutch situation can be analysed without the influence of foreign legal systems, governance models, 
and cultural differences. Each year the number of listed companies changes due to delistings, take-overs and IPOs. In 2014, 87 listed companies were included, in 2007 the results related to 122 listed companies.

\section{B Companies with Female Directors since 2007}

Figure 1 shows an increase in the number of companies with at least one female, executive or non-executive, director on respectively the Executive of Supervisory Board. In 2007, 72 per cent of the 122 companies had no female director on either of the Boards. In 2014 this situation was almost reversed, with 66 per cent of the 87 companies in the sample having one or more female directors.

Figure 1. Companies with female directors since 2005

( $\mathrm{n}$ is the number of listed companies in the sample, being all Dutch-listed companies in that year)

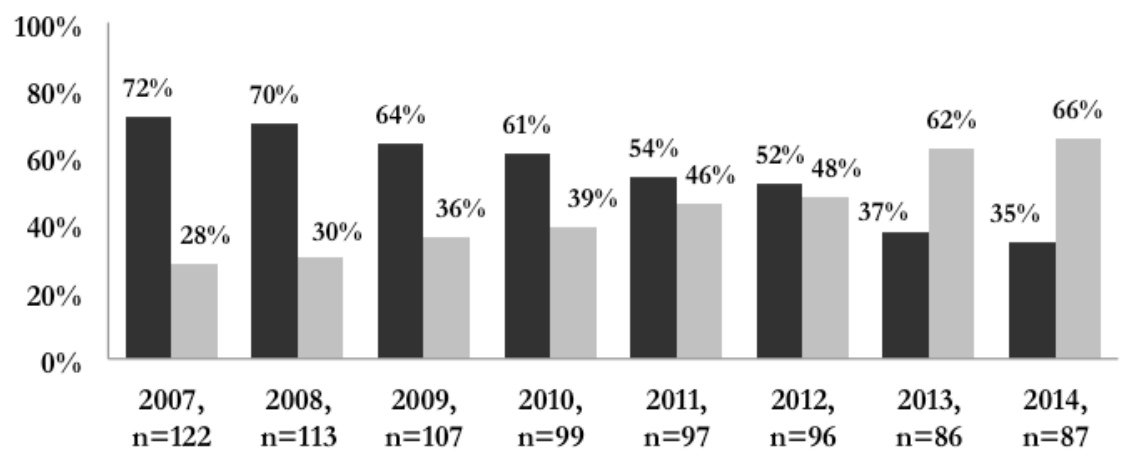

- companies with no female directors ${ }^{-}$companies with at least 1 female directors

\section{Female Directors in 2014}

Under this and the following headings the number of female directors in the 87 companies that were part of the Female Board Index 2014 will be examined. This sample will be kept constant and will show the changes within these companies. A distinction is made between all 87 listed companies and the 22 companies that are part of the Dutch 'large caps' (cap referring to market capitalisation) Index - the AEX-Index. These 22 companies are the most 
visible Dutch companies, and are the first companies that are looked at in societal discussions such as those on gender equity.

\section{$1 \quad$ Non-Executive Directors}

Figure 2 below shows the increase in the percentage of female non-executive directors at the 87 companies in the sample. In 20055.6 per cent of all nonexecutive directors, and 8.9 per cent of the non-executive directors at AEX companies, were female. This had by 2014 increased to 19.5 per cent of nonexecutive directors at all 87 listed companies, and even 25.3 per cent of directors in the 22 AEX companies.

Figure 2. Development of female non-executive directors since 2005 at the 87 listed companies in 2014

\section{$\%$ female non-executive directors}

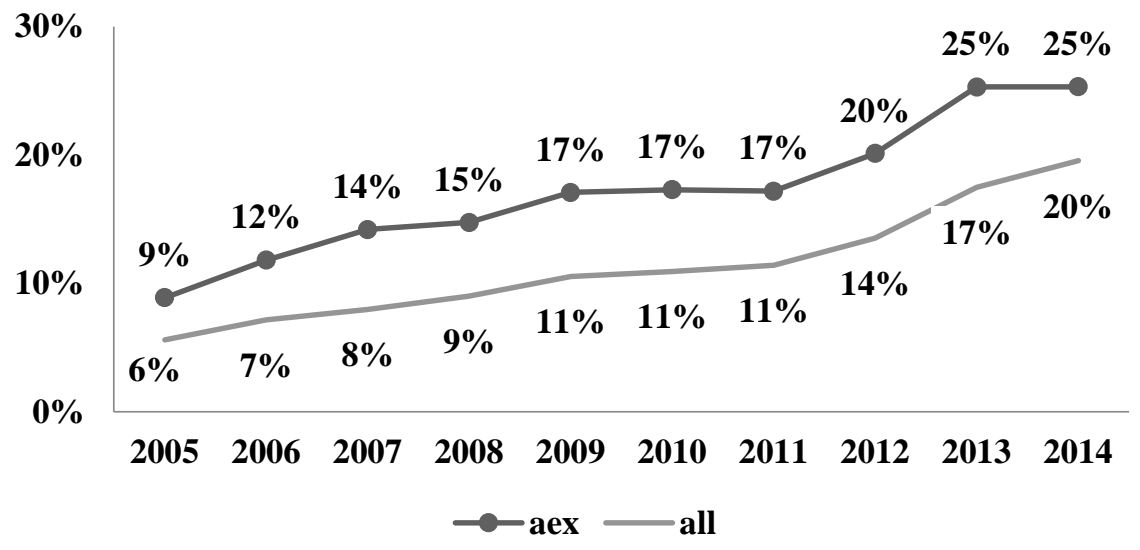

\section{Executive Directors}

Figure 3 below shows the increase in the percentage of female executive directors at the 87 listed companies in the sample. In 2014, the average percentage of female executive directors was 6.0 per cent for all 87 companies, which is almost the same as for the 22 AEX companies (5.8 per cent). This is only a small increase compared to 2005 when, respectively, 3.2 per cent and 3.4 per cent of the executives were female. It is remarkable that the percentage of female executive directors at the AEX companies dropped from 6.8 per cent in 2011 to 2.8 per cent in 2013. When the number of female executive directors is small, the resignation of, for example, two female executive directors who are not replaced has a large impact on the percentage. This was the case in 2013. 
Figure 3. Development of female executive directors at the 87 listed companies $2005-2014^{26}$

\section{$\%$ female executive directors}

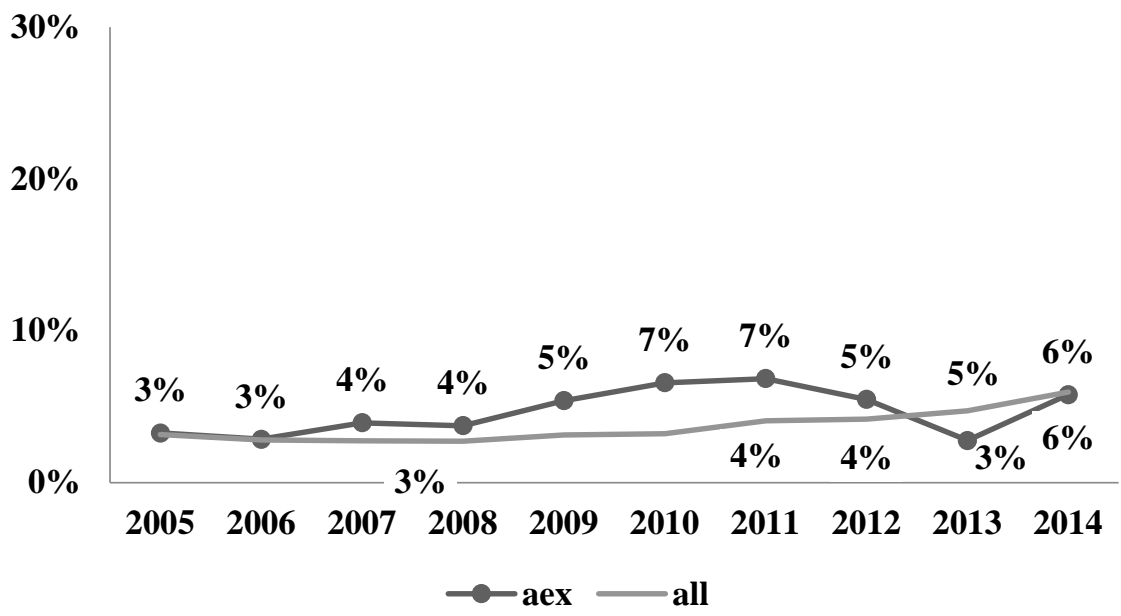

\section{Compliance with Dutch Target Law}

In August 2014, only one company ${ }^{27}$ of the 87 listed companies met the Dutch target for both boards, whereas two other companies were very close with $>30$ per cent female executives, but only 29 per cent female non-executive directors. ${ }^{28}$ Nine companies were in compliance with the 30 per cent gender target on the executive board, which was an increase of five companies compared to 2013 when only four were compliant. Sixteen companies were in compliance in 2014 with respect to the supervisory board, an increase of eight companies as compared to 2013, when only eight had complied. Furthermore,

\footnotetext{
${ }^{26}$ The 22 AEX companies are also included in the numbers and percentages of all companies ( $\mathrm{n}=87$ in 2014). The analysis is made for the 87 listed companies and their current position in the different exchange segment. This means that companies now in the AEX-segment might not have been in this segment for the whole period. Companies are excluded from the analysis when data was not complete for the respective years, for example while they did not yet exist or were not yet listed. This results in a minimum of 77 companies in 2005 (of which 18 AEX) to a maximum of 87 in 2014. For these companies the data was complete: Mijntje LückerathRovers, 'The Dutch Female Board Index 2014' (Research Report, TIAS School for Business and Society, 2014) $11<$ http://www.tias.edu/docs/default-source/Kennisartikelen/femaleboard index2014.pdf>.

${ }^{27}$ Wolters Kluwer. Ibid 18.

${ }^{28}$ TomTom and PostNL. Ibid.
} 
in 2014 seven companies (2013:2) almost met the legal requirements for the supervisory board, with 29 per cent female non-executive directors.

\section{$4 \quad$ Compliance with EU Quota}

In 2014, six companies ${ }^{29}$ (all with more than 40 per cent female non-executive directors) were in compliance with the EU target of 40 per cent female nonexecutive directors. However five of these companies had no female executive directors, so consequently they did not comply with the Dutch target law.

\section{$5 \quad$ Estimated Growth Rate until 2016}

As previously described, the articles in the Dutch Civil Code with respect to the gender target automatically terminate, and no longer apply from 1 January 2016. Figure 4 shows the real growth in the number of female directors versus the required growth. Assuming a constant rate of increase, by 1 January 2016 the percentage of female non-executive directors will be approximately 22 per cent, and of female executive directors around 8 per cent. Figure 4 also shows what the growth should be in order to comply with the Dutch target of 30 per cent at 1 January $2016 .^{30}$

Figure 4. Real growth versus required growth until 2016

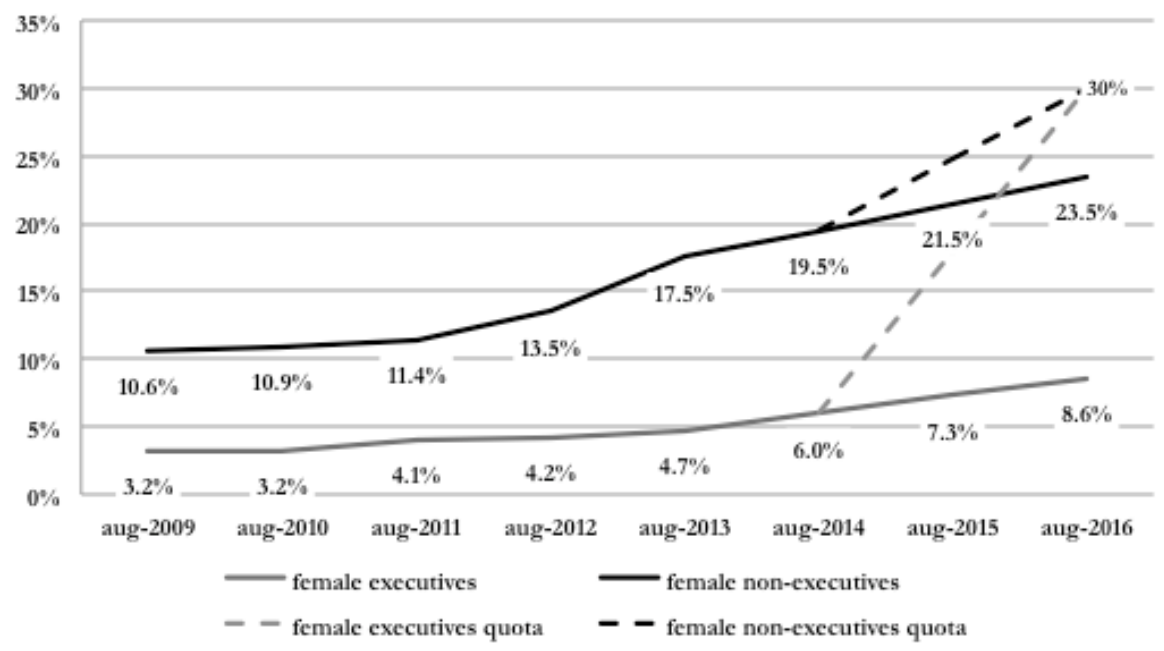

${ }^{29}$ DSM, Novisource, TMG, Snowworld, Unilever and Wessanen. Ibid.

30 The annual increase is calculated as the difference between the percentage last year (17.5 per cent for non-executives) and this year (19.5 per cent). Ibid 10. 
This means that, in absolute numbers, and for all companies together, and ignoring resignations, at least 52 female executives and 46 female nonexecutives should be added to the respective boards before January 2016. At the current growth rate the 30 per cent target for non-executives will be reached in 2020, but for executives this will only be in 2033 .

\section{THE FUTURE}

\section{A Intensified Debate...Again}

The Dutch debate again intensified after the Female Board Index 2014 was published and it became evident that the gender target will not be met before 1 January 2016. The effect of this news was given further impetus a week later when a Talent to the Top report confirmed the findings of the Female Board Index 2014 based on research among a sample of 800 companies that fell under the target law. ${ }^{31}$ According to the report the percentage of female executive directors was 8.9 per cent, and of female non-executive directors 11.2 per cent. Furthermore, this study concluded that the majority of the annual reports did not provide the 'explanation' required by the 'comply or explain' principle, which is part of the target law. Sixty-two per cent of the companies that did not comply with the 30 per cent executive board target did not explain their noncompliance, while 57 per cent of the companies that did not comply with the non-executive board target did not provide an explanation.

Jet Bussemaker, the (female) minister of Education, Culture and Science (ECS), addressed the issue on national television, and announced further steps to be taken. The absence of commentary from the other responsible Ministers is, however, surprising. It is true that emancipation is among the tasks of the Ministry of ECS, but the Management and Supervision Act, the legislation in which the targets are included, is the responsibility of the Minister of Justice, and the Corporate Governance Code is the domain of the Ministry of Economic Affairs. Both (male) Ministers have not yet expressed their opinions.

\footnotetext{
${ }^{31}$ These companies were asked to complete a survey and to provide the researchers with the requested board data: Babette Pouwels and Wilma Henderikse 'Waar een wil is, is een weg' [Where there is a will, there is a way] (Report, VanDoorneHuiskes, August 2014) 5 <http://www.talentnaardetop.nl/uploaded_files/document/Bedrijvenmonitor_2013.pdf> [author's translation].
} 


\section{POSTSCRIPT}

Recently Nancy McKinstry of Wolters Kluwer, one of the two female CEOs of listed companies in the Netherlands, wrote an article in the Dutch Financial Times (7 October 2014) entitled 'Getting Women to the Top Requires Effort from the Company Itself' ${ }^{32}$ McKinstry commented on the then current debate and stated that, 'with the debate about female quotas raging again, there's fresh focus in the Netherlands on how diversity can best be stimulated'. Although McKinstry noted that Wolters Kluwer was the only company in compliance with the target law and acknowledged that some companies would need such a quota, she also stated that 'a "female quota" has never been the means or the motivation for Wolters Kluwer'. McKinstry finds the benefits to the company of achieving diversity self-evident: '[O]ur customers are diverse, so we want and need to be diverse, too.' However, she continues that it does not happen by itself. McKinstry adds that the company expresses 'a firm commitment to stimulating diversity of all kinds', which includes 'a conscious, active policy to nurture the best talent, including that of women'. She testifies that at Wolters Kluwer it was shown that 'women are exceptionally good at teamwork and at leading diverse teams. This is a not-to-be-underestimated reason to cultivate female talent better. Diversity fosters diversity'. ${ }^{33}$

She concludes with the following statement:

[L]et us not forget why diversity - of gender, but also nationality, experience, age, skills - is important for companies. To be able to choose the best man or woman for the job, you need access to the entire talent pool. Diversity also creates more perspectives in discussions, leading to better decision-making — which has direct influence on a company's results.

Our ultimate priority is developing the most talented people, regardless of their gender, background or life preferences. As a company, we benefit from this. If all companies commit to this, the whole of society will benefit. ${ }^{34}$

\footnotetext{
32 Nancy McKinstry, Editorial: CEO Nancy McKinstry Addresses Diversity at Wolters Kluwer (7 October 2014), Wolters Kluwer <http://www.wolterskluwer.com/Press/Latest-News/ Pages/Press\%20Releases/2014/CEO-Nancy-McKinstry-addresses-diversity-at-WoltersKluwer-.aspx>.

${ }^{33}$ Ibid.

${ }^{34}$ Ibid.
} 


\section{iX Overall Conclusions}

In the Netherlands the discussion is far from over. The pressure for a mandatory quota is increasing. Although I agree with Rose ${ }^{35}$ that listed companies cannot be compared to a democracy, that no one - man or woman — has a right to be appointed to the board of a private company, and finally, that the government should not interfere with the appointments at private companies, it probably will be the only solution. As an interim solution the Minister of Education, Culture and Science, together with the influential employers association VNONCW, announced in January 2015 the establishment of a database in which the names and current positions of women qualified for (future) board positions are included. Executive search companies are bypassed by the database, which is available to companies that are looking for new female board members.

The only possible way to avoid mandatory sanctions will be a visible steepening growth rate in female board membership in 2015. If in 2015 the real growth rate as shown in Figure 4 shows a clear and sharp upward trend, especially due to the appointment of more female executive directors, it might signal that finally the breakthrough has occurred. If not, for many it will seem that there are no more excuses not to impose a mandatory quota; positions will have hardened. And that will not be good for anyone.

${ }^{35}$ Rose, above n 12, 405. 